Sixty Years of Drug Discovery for Type 2 Diabetes: Where are we now?

\title{
Drug Discovery in Type 2 Diabetes
}

John C. Clapham

University of Buckingham Medical School, University of Buckingham, Hunter Street, Buckingham, MK18 1EG, UK.

john.clapham@buckingham.ac.uk

\section{Summary}

The control of blood glucose is a dynamic interplay involving several complex systems. In diabetes these systems are perturbed, resulting in a disease continuum of progressive decline over many years. Today, excluding insulin, there are eight classes of anti-diabetic agent which have taken over 60 years to add to the pharmacy chest. In this review I have examined each of these classes with some bias towards drug discovery thinking. Based on history, future science here will be strong, progressive and innovative; the huge test for industry is their response to enormous challenges besetting drug discovery and successfully turn the drug discovery praxis into affordable, effective and safe medicines.

Key words: Type 2 diabetes; drug discovery; sulphonylureas; biguanides; incretins; DPP-IV inhibitors; thiazolidinediones; $\alpha$-glucosidase inhibitors; SGLT2 inhibitors; glinides 


\section{Introduction}

Modern drug discovery programmes often start with a hypothesis, based on some prior knowledge, that modulation of target $\mathrm{X}$ in pathway $\mathrm{Y}$ will result in a positive therapeutic effect in a particular disease area. The key to this approach is discovering the right target in the right pathway in the right tissue which is amenable to specific interaction with a ligand; a target characteristic that has been referred to as "druggability" (1). This is "target-based" drug discovery and validates drug targets using molecular genetics techniques (2), though this approach does have its critics (3). Judging by the huge failure rate, on top of patent expiration (4), this is challenging in practice, more so in complex diseases where the risks are much higher. Normal glucose homeostasis and the aetiology of type 2 diabetes are highly complex processes so predictably, drug discovery in this area has been slow with relatively few new entrants to the market in the 60 years since the introduction of today's first line drug treatment, metformin.

Maintenance of a normal blood glucose level involves a dynamic interplay between glucose absorption, glucose production and glucose utilisation. These in turn are controlled by interactions between circulating hormones (primarily insulin though many others) and the cellular processes involved in insulin (and other hormone) signalling, glucose uptake and glucose disposal. The principal tissues involved in this interplay are the liver, brain, skeletal muscle and adipose tissue which in turn differ in their patterns of substrate utilisation, production and recycling which are critical to maintaining normal blood glucose levels in the range of 3.8-6.1 mmol/1 (68.4-109.8 $\mathrm{mg} / \mathrm{dl}$ ). Following a meal, the degree to which blood glucose increases is a function of the amount of glucose absorbed, the pancreatic insulin secretory response, suppression of hepatic glucose output and increased glucose uptake by insulin sensitive (skeletal muscle, liver, adipose tissue - 65-70\%) and insulin insensitive organs (brain, kidney - $30 \%)(5,6,7)$.

Type 2 diabetes is the pathologic consequence of two concurrent and interacting conditions of insulin resistance and relative insulin deficiency. On the one hand, insulin's ability to suppress hepatic glucose output and stimulate glucose uptake and utilisation is impaired (resulting in chronically raised insulin levels), and on the other hand, the capacity of the pancreatic $\beta$-cell to maintain this hyperinsulinaemic state also begins to fail $(8,9)$. Type 2 diabetic patients are rarely hypoinsulinaemic when compared to non-diabetic individuals (8). Another twist in the natural history of type 2 diabetes story is that there is also a degenerative process that affects the normal healthy existence of the pancreatic $\beta$-cell. In a landmark study, it has been shown that after a point, a relatively small decrease in $\beta$-cell mass is all that is required to have profound effects on fasting blood glucose levels (10).

The Diabetes Control and Complications Trial (DCCT) and the UK Prospective Diabetes Study (UKPDS) have shown us that maintaining blood glucose levels to near normal levels significantly improves type 2 diabetes and its ensuing complications $(11,12,13)$. The American Diabetes 
Association has recommended that treatment should reduce HbA1c levels to less than $7 \%(14,15)$. This is a relaxation of earlier guidelines which recommended reducing HbA1c to $6.5 \%$ or below (16) as such aggressive treatment was found to be associated at best with no additional cardiovascular benefit but at worst with increased mortality $(17,18)$. However, in practise, HbA1c of $7 \%$ or above should initiate treatment regimens. Regulatory guidelines for new drug treatments usually stipulate an endpoint for a clinically meaningful and statistically significant reduction in $\mathrm{HbA1c}$, usually at least 1 $\%$ over placebo with non-inferiority against standard therapy, usually metformin.

There is a challenge that any anti-diabetic drug will face. The natural history of type 2 diabetes occurs as a continuum of the interplay described above and that occurs over many years. By the time of diagnosis the disease is already in its mid stages before any drug treatment can be initiated. The costs of treating diabetes are huge and the drugs bill is a favourite political punch bag. It is of course true; in the UK the diabetes drugs bill is expensive, in 2010 it was around $£ 2$ billion. However, the cost of hospitalisation as a consequence of diabetes was $£ 8$ billion! (Diabetes UK). It is worth noting that drug treatment with oral anti-diabetic agents may actually reduce the hospitalisation costs (19).

"Type 2 diabetes therapies" is a topic that is extensively and regularly reviewed. The aim of this chapter therefore, is to provide an overview of current drug therapy of type 2 diabetes resulting from research dating back many decades but with a flavour of the type of things that might influence drug discovery efforts in this area. It will be confined to small molecule drug inventions (though peptide drugs of the exenatide type are included). "Industrial" drug discovery for type 2 diabetes appears to have started around the mid- $20^{\text {th }}$ Century and since then 8 broad classes, excluding insulin, of agent are on the market today. These are presented in the order of their introduction.

\section{Sulfonylureas (first generation)}

Insulin secretion from the pancreatic $\beta$-cell occurs in response to an increase in blood glucose levels after a meal. Briefly, intracellular ATP levels in the pancreatic $\beta$-cell increase in response to a rise in blood glucose levels and this causes closure of an inward rectifying ion channel, the ATP-sensitive potassium channel $\left(\mathrm{K}_{\mathrm{ATP}}\right)$. This depolarises the $\beta$-cell plasma membrane, via calcium entry through L-type (verapamil sensitive) calcium channels, and stimulates insulin exocytosis (20).

Our understanding of the electrophysiology of the $\mathrm{K}_{\text {ATP }}$ channel, now combined with molecular and genomic insights, allows a comprehensive description of how sulphonylureas work. The $\mathrm{K}_{\mathrm{ATP}}$ channel is actually a multi-subunit protein complex consisting of four inward rectifying potassium channels (Kir6.2) that form a pore and four regulatory subunits $(21,22)$. There are two subtypes of regulatory subunits, SUR1 and SUR2, which differ in their binding affinities for sulphonylureas $(23,24)$. The SUR1 regulatory subunit is found in the pancreatic $\beta$-cell while SUR2 is found in cardiac and smooth muscle cells (25). 
The anti-diabetic sulphonylureas stimulate insulin secretion from the pancreatic $\beta$-cells by mimicking the effect of ATP in the $\beta$-cell to block opening of $\mathrm{K}_{\text {ATP }}$ channels $(26,27)$. They are termed insulin secretagogues.

A first generation sulphonylurea is tolbutamide. Tolbutamide originated from a war-effort search for antibiotics and the unpleasant side effect of blackouts resulting from hypoglycaemia, while unacceptable for an antibiotic, turned out to be a new therapeutic approach for the treatment of diabetes. Tolbutamide, and an analogue, carbutamide, were launched in the mid-1950s (28). Some studies have suggested that tolbutamide, because of a short duration of action, could have a place today in the treatment of elderly type 2 diabetics (29). The elderly type 2 diabetic patient is particularly vulnerable to the consequences of hypoglycaemic episodes that can make them prone to falls (30) and cardiovascular issues (29). In practice, however, tolbutamide is rarely prescribed today and carries an FDA warning regarding cardiovascular mortality.

\section{Biguanides}

The only representative of this class of anti-diabetic drug remaining in use is metformin. Although chemically synthesised, metformin is derived from biguanide compounds obtained from the medicinal plant Galega officinalis (31). It was launched in 1957 as an oral hypo-glycaemic agent. Other examples in this class were phenformin and buformin.

Metformin is poorly absorbed from the gut $(32,33)$, a process dependent on the plasma membrane monoamine transporter (34), and large doses (500 $\mathrm{mg}$ to $2500 \mathrm{mg}$ per day) are required for efficacy. The metformin molecule is not metabolised into any other product by the body and is excreted in the urine as the parent drug with the half-life of elimination of around 5 hours (35). The liver appears to be the main site of action for metformin and uptake into the liver is also facilitated by transporters, primarily OCT1 (36) but its pharmacodynamic mechanism of action in the liver has not been fully elucidated. One wonders how far metformin would have advanced through a modern drug discovery process based on current experience, yet metformin is probably the most widely prescribed antidiabetic agent in the world. The UKPDS showed that metformin out-performed standard therapies, including sulphonylurea and insulin, on all diabetic endpoints (12). It is now first line therapy in almost all markets and can be used as monotherapy or in combination $(37,38)$. Indeed, as we shall see later it has been used in combination with all of the other classes of anti-diabetic drugs because of its front-line role. Since its use is so widespread in a patient population that may already suffer from other problems requiring medication, attention needs to be paid to the potential risk for drug-drug interactions. Its reliance on the action of transporters for absorption and delivery to target organ means that other agents using these transporters will influence metformin's activity.

Unlike sulphonylureas, metformin reduces raised blood glucose levels only in the presence of hyperglycaemia and without stimulating insulin levels $(39,40,41)$. Metformin exerts its anti-diabetic 
effect primarily by enhancing the effect of insulin in suppressing gluconeogenesis and thereby reducing hepatic glucose output (42). Secondarily, metformin increases muscle tissue insulin sensitivity (43). Information is being gleaned on the pathways involved in the mechanism of action of metformin but its precise molecular target is still unknown; we do not yet know what it binds to. One of the first breakthroughs was reported in 2002 (44) which showed that metformin, and the thiazolidinedione, rosiglitazone, activated AMP-activated protein kinase (AMPK) by two different mechanisms.

AMPK is a multi-subunit enzyme playing a central role in cellular stress responses through marked pleiotropic effects on metabolism (45). It initiates cellular cascades to increase fat oxidation, decreases anabolic pathways in fat metabolism and enhances glucose uptake in order to preserve cellular energy stores (46). Thus, AMPK orchestrates the flux of fatty acids away from triglyceride synthesis and into $\beta$-oxidation via modulation of many downstream proteins. However, metformin does not bind to the AMPK complex directly to activate it; AMPK is sensitive to the cellular milieu, in this case the AMP:ATP intracellular ratio. It is suggested that metformin induces changes in the AMP:ATP ratio by disrupting normal mitochondrial function by interfering with complex 1 of the respiratory transport chain (47). This alteration of the energetic state of the cell elicits an effect on AMPK but independently of a direct interaction with the AMPK molecule. Furthermore, AMPK is itself up-regulated by other kinases lying upstream, including the LKB1 tumour suppressor protein kinase (48), which, incidentally, may also be a pathway affected by metformin. A later study however, has shown that metformin could still inhibit gluconeogenesis in hepatocytes lacking either AMPK or LKB1, perhaps via a reduction in glucose-6-phosphatase expression. Thus, the precise molecular target(s) of metformin have yet to be elucidated - somewhat anachronistic in todays "Big Data" world with emphasis on identifying precise molecular targets even before a drug discovery project starts.

Another advantage of metformin is that it associated with weight-loss in obese subjects with or without type 2 diabetes (49). This could be via activation of the oxidative pathways outlined above which can be thermogenic and increase energy expenditure (50) with an additional effect to reduce food intake (51) or a combination of both.

A rare side effect of metformin is lactic acidosis. Lactic acidosis has been reported to occur in patients with or without renal insufficiency (52). Metformin is extensively cleared via the kidneys (33) so care must be exercised in the elderly or people with a history of kidney disease. The effect of inhibiting complex 1 of the mitochondrial respiratory chain, while possibly explaining inhibition of gluconeogenesis from lactate, may also contribute to the rare cases of lactic acidosis (47). Early competitors to metformin, phenformin and buformin, were more potent and more efficacious but were eventually withdrawn in the 1970s because of higher incidence of lactic acidosis (31). Metformin can also cause severe gastrointestinal problems in some patients, possibly via an effect on bile salt 
absorption (53), though this can be mitigated to a large extent using a prolonged release formulation (54). There have been occasional reports of metformin-induced pancreatitis in both with (55) or without (56) pre-existing renal disease.

An aspect of drug discovery that has been gaining prominence over the last decade or so is the search for new indications for old (in this case very old) drugs in a drug discovery paradigm called "repurposing" (57). The potentially positive effects of metformin in cancer, polycystic ovary syndrome and non-alcohol fatty liver disease are in themselves well-reviewed areas $(58,59,60)$.

\section{Sulphonylureas (second generation)}

This group is represented by the drugs glibenclamide (glyburide), gliclizide and glimepiride. Glibenclamide was approved by the FDA in 1984. These agents are still used but predominantly as second-line add-on after metformin. As a drug class they have been extensively reviewed and metaanalysis of clinical trial data reveals that they lower HbA1c by around $1.5 \%(61)$. Hypoglycaemia is a common issue with these agents but that's hardly surprising since their mechanism of action is independent of any glucose-sensing remaining in the $\beta$-cell or the prevailing blood glucose levels. The liability for hypoglycaemia seems to be greater for glyburide than the others. Weight-gain is another common unwanted effect of this class of oral anti-diabetic agent.

The second generation sulphonylureas are metabolised in the liver via the cytochrome P450 system and eliminated via the kidneys. The biotransformation of glyburide in the liver results in the production of active metabolites (62) which will be particularly troublesome in patents with renal insufficiency. No active metabolites of gliclizide and glimeripiride have been identified.

When drugs have been in clinical use for so long and in so many patients, any lurking skeletons in the cupboard usually make themselves known. Drug discovery efforts are inconveniently, and frequently, hampered by two major causes of attrition; failure in efficacy, failure in safety or both (63).

\section{Failure in efficacy}

Although the meta-analysis reassures us that they are effective in lowering HbAlc, both as monotherapy or on top of other agents, the issue with sulphonylureas with regards to efficacy is durability. In other words, while reasonable efficacy is seen at the start of treatment, it declines with continued use $(64,65)$ in a phenomenon called "secondary failure". Secondary failure in response to sulphonylurea appears to be specific as long term treatment with sulphonylureas can selectively reduce the insulin secretory response to an acute dose of another sulphonylurea but not to glucagon (66). The exact mechanism is not known though sulphonylureas appear to induce $\beta$-cell apoptosis in cultured human islets (67). 


\section{Failure in Safety}

The other issue for the sulphonylureas is the increased risk of cardiovascular side effects, an issue that has been debated since the 1970s. The sulphonylurea glyburide was shown to have a greater risk of cardiovascular mortality than metformin (68) in a study that raised the question about the manner in which blood glucose can be safely reduced. Since then several studies, using metformin as a comparator, have reported that a number second generation sulphonylureas share this cardiovascular risk $(64,65)$. There also appears to be differences between different sulphonylureas on the degree of risk (67). Increased cardiovascular risk with these agents is probably beyond doubt now and has serious implications for developing economies that rely on cheap drugs (69) as preferred treatments.

The increased cardiovascular risk is probably due to the interaction with cardiac $\mathrm{K}_{\mathrm{ATP}}$ channels (70). In patients with already increased risk of cardiovascular disease sulphonylureas acting on cardiac $\mathrm{K}_{\text {ATP }}$ could mask ST-segment elevation causing opportunities for life-saving interventions to be missed (71).

\section{Thiazolidinediones}

The thiazolidinediones troglitazone, rosiglitazone and pioglitazone were launched in the late 1990s. They exert their anti-diabetic effects principally by alleviating insulin resistance. Unlike metformin, whose main site of action is the liver and secondarily skeletal muscle, the thiazolidinediones act primarily on adipose tissue and secondarily skeletal muscle. The molecular mechanism of the thiazolidinediones is activation of the nuclear hormone receptor, Peroxisome Proliferator Activated Receptor- $\gamma$ (PPAR- $\gamma)$. There are a number of classes of PPAR (72) and all appear to be involved in the regulation of metabolism, for example PPAR- $\alpha$ activates pathways for fatty acid oxidation (73). The thiazolidinediones mentioned above were not a result of rational drug design based on knowledge of their molecular target but rather through the observation that certain drugs, fibrates, originally developed for dyslipidaemia and acting via PPAR- $\alpha$, lowered blood glucose levels but through a different, then unknown, mechanism. They were well into their clinical development when PPAR- $\gamma$ was identified as their primary molecular target; the thiazolidinediones were identified by what we now call phenotypic screening, the precursor methodology to target-based approaches. However, almost from the start, they were beset with problems.

Troglitazone, which was approved in 1997, was shown to be efficacious as monotherapy or in combination with sulphonylureas or metformin (74). But there were early signs of trouble, even in clinical trials there were indications of the hepatotoxicity (75) that eventually led to its withdrawal from the UK market in 1997 and the US market in 2000. The background to this story and the reasons for the almost immediate withdrawal by GlaxoSmithKline in the UK and its persistence on the US and Japanese markets is sobering reading and underlies how different companies have very 
different attitudes to patient safety risk (76). The other thiazolidinediones, rosiglitazone and pioglitazone did not share this particular liability.

Rosiglitazone and pioglitazone are efficacious, they lower HbA1c by between 1.0 and $1.5 \%$ over placebo control in monotherapy trials (65). They did however cause fluid retention and an increase in body weight (77). The thiazolidinediones also lower elevated free fatty acids, particularly in combination with metformin $(78,79)$. This is good and has the potential to reduce lipotoxicity which is thought to be a mechanism contributing to $\beta$-cell dysfunction in type 2 diabetes $(80,81)$. Long term-treatment of $f a / f a$ rats with rosiglitazone, using either prevention or intervention protocols, has hugely beneficial effects on islet morphology (82). Together these sets of results suggest that the thiazolidinediones could have had the potential for improving $\beta$-cell health. Sadly, we will never know for sure as further calamity overtook this class of agent.

Two very controversial meta-analyses suggested that rosiglitazone increased risk of myocardial infarction $(83,84)$. The resulting public outcry and media storm $(85)$ condemned the drug and led to its withdrawal by the company in 2007 even though an FDA advisory committee didn't think that there was sufficient evidence to actually call for its withdrawal (86). The methodologies in the metaanalyses have been subsequently questioned and other studies did not find the increased risk of myocardial infarction, and perhaps even a positive finding for rosiglitazone $(87,88)$. This controversy seriously knocked the confidence of patients and physicians but it is sad to note that the manufacturer no-longer invests in in-house diabetes drug discovery research. In late 2013, after reviewing the data of Rosiglitazone Evaluated for Cardiovascular Outcomes and Regulation of Glycemia in Diabetes (RECORD) trial (89), the FDA removed marketing restrictions on rosiglitazone but the patent on rosiglitazone had expired in 2012.

But the pain did not end there. Pioglitazone sparked some further concern surrounding increased risk of bladder cancer (90). Thiazolidinediones are is also associated with fractures, particularly in postmenopausal women (91) and macular oedema (92) which appears to be reversible on discontinuation of therapy (93).

Thiazolidinediones are available in their generic form but really only as third line therapies.

\section{$\alpha$-Glucosidase Inhibitors}

Carbohydrates constitute a large proportion of our energy intake, especially for those of us living in the Western world. Worryingly, over the last 50 years or so the proportion of refined sugars entering our diet has also increased dramatically $(94,95)$ as we consume more and more processed foods. The majority of the carbohydrate consumed in food is polysaccharide in the form of starch or oligosaccharides such as sucrose. 
Monosaccharides, such as glucose, are readily absorbed through the intestinal epithelium via the sodium-dependent glucose co-transporter-1 (SGLT1) (96). Oligosaccharides and polysaccharides are not readily absorbed and have to be broken down to monosaccharides first. Starch is broken down into smaller oligosaccharides by $\alpha$-amylase in the small intestine. The resulting oligomers (or dietary oligomers) are further broken down by a membrane-bound enzyme family into (primarily) glucose, galactose and fructose (97) which can then be transported through the gut epithelia and on into the blood stream. These latter enzymes reside in the brush border of the small intestine and are the $\alpha$ glucosidases (formally known as the maltases) and they hydrolyse O-linked glycosidic bonds (98). As mentioned in the introduction with regards to a potential drug discovery programme, a clear hypothesis presents itself here; sugar consumption is increasing and so is type 2 diabetes. In the absence of restraint from ourselves or moderation of added sugars to processed foods by manufacturers, inhibition of $\alpha$-glucosidases by drugs will reduce absorption of dietary sugar and the hypothesis assumes that this will improve glycaemic control, and this is essentially what has happened. The $\alpha$-glucosidase inhibitors, acarbose, voglibose and miglitol are pseudo-carbohydrates and were launched between 1994 and 1996. Acarbose and voglibose are poorly absorbed and are consequently excreted in the faeces (99) while miglitol is fully absorbed and excreted as parent compound by the kidneys (100).

Acarbose has been shown to be an effective monotherapy where diet modification is insufficient to control fasting plasma glucose. A marked reduction in postprandial hyperglycaemia was reported in one study where a $0.65 \%$ reduction in $\mathrm{HbA1c}$ after 24 weeks treatment was observed (101). The efficacy of acarbose is reasonable compared to other oral anti-diabetic agents such as metformin and gliclizide $(102,103)$. $\alpha$-glucosidase inhibitors may also be useful in reducing insulin requirement of type 1 diabetic patients (104). Side effects of the $\alpha$-glucosidase inhibitors are, unsurprisingly, mainly gastrointestinal; diarrhoea, flatulence and abdominal distension (meteorism).

The $\alpha$-glucosidase inhibitors also appear to have a positive effect on disease markers of cardiovascular dysfunction (105), an effect that may be related to the suppression of postprandial hyperglycaemia seen with these agents. Postprandial hyperglycaemia is associated with oxidative stress (106) and oxidative stress is linked to vascular endothelial dysfunction $(107,108)$. Thus the $\alpha-$ glucosidase inhibitors have the potential of being a useful add-on treatment to existing anti-diabetic agents to improve postprandial hyperglycaemia and perhaps could confer benefits with regard to cardiovascular function.

\section{Meglitinides}

The insulin response to glucose occurs in two phases; an immediate early phase increase within minutes and a later, more prolonged increase over 2-3 hours. The biphasic nature of the insulin response is more discernible in response to intravenous administration of glucose but the episodic 
nature of the insulin response to prandial glucose is less clearly defined (109). The liver is an important target organ for the early phase insulin response, where insulin acts to suppress hepatic glucose output $(110,111)$.

In type 2 diabetes there is a loss of the early insulin response to a meal and this may be a marker for impairment at the level of the $\beta$-cell $(112,113)$. Thus, restoring the first phase insulin response is an important therapeutic goal (114). An early proof of concept to this idea was shown in newly diagnosed type 2 diabetics; insulin was infused to mimic the first phase insulin response and resulted in a marked reduction in elevated post prandial glucose excursions (115). Thus, the hypothesis that drugs that restore first phase insulin response will produce an important beneficial therapeutic effect was a clear "go" signal for project work.

The meglitinides are short-acting insulin secretagogues that are readily absorbed from the gastrointestinal tract (116). This makes them a much more suitable option than infusing insulin. Examples of these agents are repaglinide and nateglinide launched in 1997 and 2000 respectively. Like the sulphonylureas the meglitinides reduce the probability of $K_{\text {ATP }}$ channel opening in $\beta$-cells to depolarise the cell by allowing calcium influx through L-type calcium channels (117). Repaglinide and nateglinide also bind competitively to the SUR1 sulphonylurea receptor with Ki of 100 and 240 $\mathrm{nM}$ respectively compared to $2.3 \mathrm{nM}$ for glibenclamide (118). Furthermore, nateglinide differs from repaglinide in that it dissociates from the SUR1 receptor very rapidly (118).

Clinical experience, either as monotherapy or in combination, show that this class of anti-diabetic agent are effective, particularly with respect to meal time glucose excursions. For example, in a double-blind, placebo-controlled study, repaglinide $(0.5-1.0 \mathrm{mg})$ taken at meal times improved glycaemic control and reduced $\mathrm{HbA} 1 \mathrm{c}$ by $1.14 \%$ after 4 weeks of dosing without a significant effect on body weight (119). This study also highlighted the flexibility of these agents; repaglinide has a rapid onset of action and short duration and has utility where meal patterns may change from day to day. In a 16-week head to head trial, repaglinide and nateglinide were compared as monotherapies in type 2 diabetic patients (120). While both agents has similar effects on post-prandial glucose excursions, repaglinide was more effective at reducing $\mathrm{HbA1c}$ and fasting plasma glucose though it did induce more weight gain than nateglinide. While repaglinide and nateglinide both block the $\mathrm{K}_{\mathrm{ATP}}$ channel, their mode of interaction with the regulatory subunit, SUR1, differs (121) which may partly explain their therapeutic differences. Similarly, repaglinide was shown to be slightly more effective that the sulphonylurea, glipizide (122).

The meglitinides are unlikely to be a first-line drug therapy; as the majority of patients will be on metformin, however, where metformin is contraindicated these agents may be used (123) but there are questions with regard durability of effect and long term usefulness as monotherapy (124).

Meglitinides may still be a useful add-on therapy in subjects where their diabetes is still hard to 
control despite diet, exercise and metformin treatment. In such a case, addition of repaglinide resulted in better control compared to metformin (or repaglinide) monotherapy (125). Weight gain was reported as was a greater incidence of mild to moderate hypoglycaemic incidents.

The rapid onset and short duration of action of the meglitinides seems to confer advantages over the second generation sulphonylureas with respect to post prandial glucose control and their pharmacokinetic properties allows flexibility with respect to meal patterns. As we saw with the $\alpha$ glucosidase inhibitors, this property will have other beneficial effects, particularly on cardiovascular risk, and this does seem to be the case for repaglinide compared to the sulphonylureas (126).

\section{Incretins}

\section{GLP-1 mimetics}

The discovery of the polypeptide hormones, glucose-dependent insulinotropic polypeptide (GIP) and glucagon-like peptide-1 (GLP-1) followed from the well-known observation that oral, but not intravenous, administration of glucose enhanced insulin secretion from pancreatic $\beta$-cells (127). These are the incretin hormones and both GIP and GLP-1 are major contributors to meal-induced insulin secretion (128). GIP is secreted from duodenal K-cells while GLP-1 is secreted from L-cells located further down the gastrointestinal tract at the distal ileum and colon (129). Glucose sensing by SGLT1 plays a crucial role in the stimulus-secretion coupling in L-cells (130). GLP-1 reduces the secretion of glucagon from pancreatic $\alpha$-cells to reduce glycogenolysis while GIP increases glucagon secretion. In the blood stream both GIP and GLP-1 are rapidly inactivated by N-terminal cleavage of 2 amino acids by dipeptidyl peptidase IV (DPPIV). Within the 2-4 minutes that the incretins are active, they interact with GIP receptors and GLP-1 g-protein coupled receptors on the pancreatic $\beta$ cell to affect an increase in cAMP and ultimately insulin secretion $(131,132,133)$.

The biology of GIP and GLP-1 has been well documented and the reader is referred to a comprehensive review where their biology has been compared and contrasted (134). The first objective for a therapeutic agent activating the incretin pathway will be to have an active half-life for considerably longer than the 2 minutes enjoyed by GLP-1. This goal spurned a great deal of industrial activity to screen and identify a small molecule agent to activate the GLP-1 receptor. Agonists are harder than antagonists to identify and Class-B GPCRs are notoriously resistant to drug discovery efforts. This is because of a large and complex N-terminal domain that appears to shield the extracellular binding face of the receptor; to activate the receptor peptide ligands have to bind to both the N-terminal domain and to the active site (135). Since the GLP-1 receptor is a Class-B GPCR and an agonist is the therapeutic modality, the odds were stacked against small molecule discovery efforts from the start. Small molecule approaches have been traditionally preferred because they, in the main, are oral therapies. There have been many attempts to identify small molecule activators of the GLP-1 receptor using the shotgun approach of high throughput screening. It is likely that millions 
of compounds from a variety of libraries from several companies were screened to largely no avail. However, there are some examples of small molecule agonists of the GLP-1 receptor (136).

Molecules of interest, arising from research in China, are substituted cyclobutane compounds which appear to avoid the barriers to small molecule activation of the GLP-1 receptor. The lead compound, designated Boc5, appears to exert GLP-1 agonistic effects in animal models of diabetes $(137,138)$. Sadly, these are non-druggable molecules (136), meaning that there is little or no scope for optimisation, but they at least encourage us that a small molecule approach is not as improbable as we originally believed.

However, in the present world, the main therapeutic GLP-1 agonists are all peptidic, and therefore require injection. Analogues of GLP-1, such as exenatide which was approved in 2005 and liraglutide which was approved in 2010 were the results of the effort to find longer acting GLP-1s. Unlike the very short half-life of native GLP-1, exenatide has a half-life of around 2.5 hours (139) which still necessitates multiple daily doses. Liraglutide, a fatty acid derivative of GLP-1, was approved in 2010 and displays a much longer half -life as a result of this modification (140). The HbA1c lowering of GLP-1 mimetics is related to half-life and a longer-acting version of exenatide was introduced which allowed for once weekly dosing (141).

The anti-diabetic effects of exenatide and liraglutide have been extensively reviewed (142) and have been shown to be effective treatments in trials either as monotherapy or in combination; in real-world medicine they are more likely to be given in combination. It is possible that liraglutide outperforms exenatide with respect to HbA1c (143) but that the effect is marginal and the longer-acting version of exenatide may mitigate this difference. These agents have some interesting side properties that are beneficial - in future these additional properties (over and above HbA1c lowering) will determine the commercial success of any agent for the treatment for type 2 diabetes. Exenatide has been shown to lower body weight, most likely mediated by a central effect on appetite $(144,145)$. This may be very useful in the treatment of hyperphagic obesity of hypothalamic origin (146,147). Given the experience with the thiazolidinediones and sulphonylureas this is a desirable add-on effect in drug discovery programmes.

$\beta$-cell decompensation (148) and declining $\beta$-cell mass (10) are key morbidities in the type 2 diabetes continuum. Therapeutic agents that could reverse this decline in $\beta$-cell mass would be game changers as this would result in the in vivo generation of new $\beta$-cells. As we have seen, the thiazolidinedione drug class may have had this ability via an attenuation of lipotoxicity, but the world will never really know. However, the general idea of reversing the decline in $\beta$-cell mass is generating plenty of interest as a biological effect area in its own right with the realisation that the pancreas is actually flexible enough to generate new $\beta$-cells either by replication or by neogenesis (149). 
It seems that drugs acting via the incretin system appear to have very interesting effects on $\beta$-cell biology with the finding that GLP-1 mimetics appear to improve measures of $\beta$-cell function (150) or responsiveness (151) in diabetic patients. However, this sort of finding does not imply the effects are due to neogenesis which is currently impossible to measure in living patients. Experimental data from animals (152) and from isolated human islets (153) suggests that this is an area indeed worthy of continued study especially in the clinical setting. In another twist to the biology of GLP-1 mimetics, exenatide has been shown to reduce $\beta$-cell apoptosis in neonatal rat or human isolated islet preparations $(154,155)$, one of the destructive influences on $\beta$-cells in type 2 diabetes (156). Sadly, since $\beta$-cell depletion by apoptosis is a process that occurs over many years it is hard to envisage a viable clinical study protocol designed to confirm that an anti-apoptotic effect contributes to improvements in $\beta$-cell function or mass. As we have seen before (10), after a certain point, only a small reduction in $\beta$-cell mass results in overt hyperglycaemia. Conversely, perhaps only a small increase in $\beta$-cell mass could delay the switch-over to overt, insulin requiring diabetes. However, expansion of $\beta$-cell mass in mice may be different and perhaps more amenable than in human islets as the difference in islet structure, and perhaps behaviour, between the two species is marked $(157,158,159)$.

Despite the promise of some very interesting pharmacology with regards to glycaemic control, weight loss and perhaps $\beta$-cell mass, a potentially very serious safety concern has been flagged and this has been hotly debated; acute pancreatitis and pancreatic cancer. If probable expansion of $\beta$-cell number is due to a proliferative effect, could this occur in other cell types?

Pancreatitis was reported as a potential risk by the FDA in late 2006 and has been subsequently confirmed in many studies (160). This article summarises these reports and offers a plausible mechanism for this side effect. Briefly, GLP-1 receptors are present in pancreatic duct cells (161) and following chronic stimulation of these receptors during treatment with GLP-1 mimetics the duct cells may proliferate and block pancreatic ducts leading to pancreatitis and ultimately pancreatic cancer (160). The degree of risk posed by these agents has been challenged on the basis that the data neither proves nor disproves the hypothesis that the acute pancreatitis progresses to malignant disease (162). Nevertheless, diabetes is itself a risk factor for pancreatitis (163) and extreme care must therefore be taken if agents have the potential to superimpose risk where there is already vulnerability.

\section{DPPIV Inhibitors}

An alternative strategy to the very challenging approach of producing Class-B GPCR agonists is to extend the half-life of the endogenous hormones; this has been achieved by inhibiting the DPPIV enzyme. This is generally an easier option for the drug hunter and pharmaceutical industry. 
DPPIV is a 766 amino acid glycoprotein and is well conserved across species, which is very useful from a drug discovery perspective to reduce the number of screens required. It is a serine protease, so called due to the presence of a serine residue in a catalytic triad comprising serine-624, aspartic acid702 and histidine-734. As a serine protease DPPIV removes a dipeptide from the $\mathrm{N}$-terminus of peptide hormones of around 30 amino acids in length and recognises its substrates via amino acid motifs. For DPPIV, peptides which have proline or alanine as the penultimate amino acid are favoured substrates (i.e. $\mathrm{N}_{2} \mathrm{H}$-x-Pro-). Although well conserved across species, DPPIV lacks similarity to the classical serine proteases such as chymotrypsin (164). However, there are other peptidases that favour the $\mathrm{N}_{2} \mathrm{H}$-x-Pro- motif, DPPVIII and DPPIX, where inhibition of these enzymes, as an off-target effect, could result in severe adverse effects (165).

DPPIV is a Type 2 cell surface protein in terms of its spatial arrangement; most of the heavily glycosylated molecule is exposed to the extracellular space and is anchored to the cell membrane by virtue of a transmembrane helix anchor (166). A soluble form of DPPIV, which lacks the anchor, was discovered in human plasma (167). In the context of its therapeutic role its most important substrates are GIP and GLP-1. However, neuropeptide Y (NPY), peptide YY, Substance P and chemokines such as RANTES are also substrates; indeed we have found that DPPIV inhibition enhances the antilipolytic activity of NPY in human adipose tissue (168). The crystal structure of DPPIV was solved in 2003 (169) and subsequently many structures have been published co-crystallising DPPIV with small molecule ligands and peptides (170). This is a hugely valuable resource in drug discovery as it increases confidence and facilitates rational drug design.

Therapeutic inhibitors of DPPIV fall broadly into three types: Reversible substrate analogues (no example on market), covalently bound substrate analogues such as vildagliptin and saxagliptin and reversible non-peptidic heterocycles such as sitagliptin (171). The development path for launch of sitagliptin is worthy of mention. Sitaglitptin (MK-0431) was nominated as the lead candidate for development in January 2002 and by only 2006 was approved by the FDA and by the EMEA the following year, this was a spectacular achievement for Merck and was an example to the industry of what clear planning and crisp decision making looks like. Sitagliptin was the first DPPIV inhibitor to market.

This drug class has been extensively reviewed for example: $(165,172,173,174,175)$. All marketed DPP-IV inhibitors show augmentation of GIP and GLP-1 levels and produce broadly similar reductions in $\mathrm{HbA} 1 \mathrm{c}$ of around $-1-1.5 \%$, close to that produced by metformin. However, metformin is superior with respect to fasting plasma glucose levels. DPP-IV inhibitors have a low risk for hypoglycaemia in monotherapy and are weight neutral. All DPPIV inhibitors can be given with other oral hypoglycaemic agents and as the diabetes advances they can be given with insulin in the late stages of the disease where perhaps combination with metformin fails to produce the desired level of glucose control (176). 
As expected for agents working in a common pathway, similar effects of DPP-IV inhibitors to GLP-1 mimetics on $\beta$-cell biology have been reported. Clinical studies in type 2 diabetics also show an apparently beneficial effect on the $\beta$-cell when using the insulin: proinsulin ratio as a surrogate of $\beta$ cell function $(177,178,179)$. Animal studies, where $\beta$-cell mass can be measured directly, show that DPP-IV inhibition preserves (perhaps increases) $\beta$-cell mass (180). Also not surprising is that acute pancreatitis, and the same associated issues, has also been reported with the DPP-IV inhibitors in some $(181,182)$ but not all $(183)$ studies. While there are no reports of improved cardiovascular outcomes, DPP-IV inhibitors as a class, with perhaps the exception of sitagliptin, appear to be relatively free from major adverse cardiovascular events (184).

Where there are agents with different modalities acting in the same pathway comparison is inevitable. In one study comparing outcomes of GLP-1 receptor agonists and DPP-IV outcomes the conclusion was that the GLP-1 receptor agonists were superior in terms of HBA1c and body weight reduction (185). They also conclude, quite diplomatically that since DPP-IV inhibitors can be taken orally rather than by injection and where overweight is not a medical issue, DPP-IV inhibitors may be preferred. Nevertheless it does indicate that there is useful flexibility in treatment options.

\section{SGLT2 inhibitors}

The SGLT2 inhibitors are the latest oral anti-hyperglycaemic agents to be approved and launched. Their rationale is based on the hypothesis that increasing glucosuria will facilitate glycaemic control by removing glucose from the blood. In healthy individuals, plasma glucose levels are maintained between $3.8-6.1 \mathrm{mmol} / \mathrm{l}(68.4-109.8 \mathrm{mg} / \mathrm{dl})$. All plasma glucose is filtered freely through the glomerulus and into the proximal convoluted tubule yet less than $1 \%$ of this glucose enters the loop of Henle, it is virtually all reabsorbed into the circulation. Glucose is a highly polar molecule; it will not diffuse across biological membranes on its own and a sodium-potassium ATPase is required to power a sodium concentration gradient that provides the drive to transport glucose across the membrane via a sodium-glucose co-transporter. There is a family of renal sodium-glucose transporters and their molecular biology and biochemistry are very well reviewed $(186,187)$.

The highly industrialised process of glucose reabsorption from the tubular lumen occurs in the earlier part of the proximal convoluted tubule where over $80 \%$ of all the glucose is reabsorbed (186). It is mediated by a high capacity, low affinity sodium-glucose co-transporter (SGLT2) present in the luminal brush border membrane. Further along the proximal tubule there is a low capacity, high affinity sodium-glucose co-transporter (SGLT1) which accounts for the remaining glucose removal. Although SGLT2 and SGLT1 differ in their capacities and affinities they both operate via a common mechanism (188). SGLT2 was cloned in 1992 (189) and is expressed at very high levels in the early proximal tubule (190) very suggestive of a bulk transport role. 
Over the course of 24 hours the kidneys of a normal individual will have reabsorbed over 160 grams of glucose (191) which equates to "energy conservation" of the order of $2560 \mathrm{~kJ}$ (600 kCal) per day. This degree of reabsorption is well within the maximum renal absorptive capacity for a normal individual and gives the system resilience. However, when plasma glucose levels exceed $10.0 \mathrm{mmol} / \mathrm{l}$ $(180.0 \mathrm{mg} / \mathrm{dl})$, as seen in diabetes, glucose starts appearing in the urine - glucosuria.

Before significant investment is committed to initiating and progressing drug discovery programmes various levels of comfort are required. The highest level is of course when a first-in-class drug is successfully launched; but then it really should be too late for anyone else to follow because of the decade long lead time. Commonly in drug discovery projects, some form of human target validation is sought early in the projects lifetime, perhaps even before a formal investment decision. For SGLT2 there was luck in two respects. Firstly, a form of human target validation presented itself in the form of loss of function mutations (human gene knock-outs if you will) that exist and result in glucosuria $(192,193)$. Secondly, there was a competitive inhibitor that has been known to science since the mid1880s: phlorizin, a naturally occurring dihydrochalcone glucoside found in the bark of pear, apple and cherry trees. In a study conducted in the 1930s phlorizin was reported to promote glucosuria and reduce plasma glucose levels in humans (194). In a reversal of the normal linear process, fifty years elapse in order to find a study in animals where phlorizin was shown to ameliorate hyperglycaemia and, interestingly, improve insulin sensitivity in partially pancreatectomised diabetic rats (195). Phlorizin was subsequently found to be a competitive inhibitor of SGLT2 with a Ki of around $220 \mathrm{nM}$ (187). For a project start-up this is 'gold dust'!

However, phlorizin has a number of issues: 1) it is poorly absorbed, 2) it is non-selective with regard to other SGLTs, 3) it is poorly bioavailable, and it needs to get to its target, and 4) has unpleasant gastric side effects probably due to point 2 ). These are all features that can be fixed by a decent medicinal chemistry approach and indeed the currently approved SGLT2 inhibitors used phlorizin as a molecular starting point. Early attempts were not so successful since they, like phlorizin itself, were O-linked glycosides and very prone to rapid metabolism (196). This was solved by changing the Olinked bond to a C-glucosidic bond to yield canagliflozin (197), dapagliflozin (198) and empagliflozin (199) which gained FDA approval in the order cited here between late 2013 and autumn of 2014. The structural parameters in order to mass-produce SGLT2 inhibitors are well defined (200) as evidenced by these approvals occurring in rapid succession with yet others waiting in the wings $(201,202)$. This may well be a drug class where the "me-too" criticism may well resurface. Differentiation will then be a challenge to get a decent return on investment and additional benefit to the patient.

Although on the market for a relatively short time there have been several reviews of the SGLT2 inhibitors in diabetes $(199,201,202,203,204)$. As a class they appear to have good pharmacokinetic properties $(205,206)$ and access their molecular target from the luminal side of the proximal tubule (207). They are well tolerated $(205,208)$ and reduce HbA1c by the usual $1 \%$ or so over placebo 
$(199,197,203)$. They also appear to be good, perhaps excellent, add-on therapy to metformin, glimeperide, sitagliptin and insulin $(203,204)$.

Given that all of the energy contained in glucose is not recycled following SGLT2 inhibition, weight loss is perhaps not surprising $(209,210)$ and could even be a useful add-on to problematic agents like sulphonylureas where weight gain is a concern (211).

One potentially serious issue that needs careful monitoring is the increased risk of urinary tract infections and an increase incidence has been reported for all members of this class $(205,208)$. In an analysis of the literature sponsored by one of the manufacturers they could not find a definitive dose relationship between SGLT2 inhibitors and urinary tract infection (212). Of course, the infection risk may well be real, just not related to the dose of drug, it boils down to a question of the integrity of protocol design. Despite this, there has not yet been sufficient time to lapse given the years that diabetic patients will be on their treatments, and given the track record of other classes of drugs when they get into clinical practice, careful monitoring of safety and durability is essential.

There are early signs of additional cardiovascular benefit in this class - a major boon for an oral anti diabetes therapy - the use of these agents as add-on therapy to metformin and the results of large cardiovascular outcomes trials, DECLARE TIMI-58 for dapagliflozon (213) and EMPA-REG for empagliflozin (214) are eagerly awaited.

An increasingly important challenge for pharmaceutical companies is to demonstrate that their new drug is cost effective, especially where tax-payers money is involved. Although not mentioned for the previous drug classes, these agents were launched at a time where costs of medicines have never been higher on the agenda of the funders and is worth commenting on. Despite a very optimistic cost benefit analysis performed by the manufacturer, it does seem that these agents do have some modest cost benefits when modelled using more stringent methods, particularly when compared to sulphonylureas, pioglitazone and DPP-IV inhibitors (215). In subjects with uncontrolled diabetes cost savings may be indirect. A retrospective study in such patients from India showed that in "real world clinical practice" there was a compensatory reduction in the amount of insulin required by these patients (216).

\section{Where are we now?}

In this chapter I have attempted to outline the 8 classes of antidiabetic drugs in the chronological order of their appearance as medicines since the 1950s from a drug discovery perspective; so quite a narrow perspective. What is evident is that these agents are the result of research and development activities performed in pharmaceutical companies using knowledge originating from academic research. In future this paradigm will have to remain the norm. However, pipeline attrition in this disease area is high, numerous publications have appeared on new drug targets optimistically predicting a novel approach only to ultimately end in failure, with Stearoyl-CoA Desaturase-1 (SCD-1) (217), 11 $\beta$ - 
hydroxysteroid dehydrogenase-1 (11ß-HSD-1) (218) and Diacylglycerol acyl transferase-1 (DGAT-1) (219), being relatively recent examples. Nevertheless, potential future targets for type 2 diabetes are reviewed frequently $(220,221,222,223)$ showing that science can deliver new ideas. In particular, a class of GPCRs, the fatty acid receptors, seem to be very interesting in this therapeutic area (221). However, for there to be a real future for anti-diabetes drug development there needs to be a vibrant pharmaceutical industry with the ability to invest in, or facilitate, the whole journey. Today the costs involved in bringing a drug to market are enormous and appear to have risen hugely over the past decade or so. A report published in 2011 suggests that the cost is between 0.3 and 0.9 billion dollars per drug (224). However, this analysis does not seem to account for the global costs involved which includes the potentially debilitating costs of failure which have caused serious productivity issues in the industry (225). An article in Forbes (226) using a rather simplistic but useful calculation where total research and development expenditure over a 10 year period was divided by the number of product launches over the same period. This revealed a truly shocking reality - drug discovery in the pharmaceutical industry as we know it today is unsustainable. The numbers suggest that the giants with greatest loss of productivity are spending in excess of $\$ 10 \mathrm{bn}$ per drug launch. The industry has been forced to undergo change, often traumatic as many ex-employees will testify, and there is also the risk of retrenching effort away from the high risk high cost endeavours such as chronic diseases to areas where risk can more comfortably be predicted and managed.

Apart from cost the next challenge is return on investment, what can new drugs be reasonably sold for? New modalities such as antibody therapeutics seem to hold many possibilities not dreamed of by small molecule mind-set that I was involved in when I started my career in the 1970s, but they are very expensive which could render them unaffordable no matter how good they are, particularly in the developing economies where future need will be greatest. Then there is the developing sophistication of users and prescribers who will demand more than just HbA1c lowering; weight loss and improved cardiovascular outcomes have been seen with agents though this was probably a result of serendipity, this is much harder to design in from the beginning. Disease reversal may also be a demand if $\beta$-cell biology delivers. Also, new drugs are going to have to be very safe, probably the hardest thing of all as nasty surprises are often revealed post-launch as drugs are prescribed to much larger numbers of patients and the thiazolidinedione story and the more recent potential pancreatitis issue with the incretin agents and urinary tract infection risk with the SGLT2 inhibitors are heightening awareness. Highly effective, safe and affordable drugs are still urgently needed and type 2 diabetes is I believe still an unmet medical need despite six decades of drug discovery research. The prospects are not impossible but the probability is hard to predict. 


\section{References}

1. Sugiyama Y. (2005) Druggability: selecting optimized drug candidates. Drug Discov Today $10,1577-1579$

2. Allen M.J., Carey A.H. (2004) Target identification and validation through genetics. DDT: Targets 3, 183-190

3. Sams-Dodd F. (2005) Target-based drug discovery: is something wrong? Drug Discov Today $10,139-147$

4. Paul S.M., Mytelka D.S., Dunwiddie C.T., Persinger C.C., Munos B.H., Lindborg S.R., Schact A.L. (2010) How to improve R\&D productivity: the pharmaceutical industry's grand challenge. Nat Rev Drug Disc 9, 203-214

5. Bouzakri K., Koistinen H.A., Zierath J.R. (2005) Molecular mechanisms of skeletal muscle insulin resistance in type 2 diabetes. Curr Diabetes Rev 1, 167-174

6. Gerich J.E., Mitrakou A., Kelley D., Mandarino L., Nurjhan N., Reilly J., Jenssen T., Veneman T., Consoli A. (1-2-1990) Contribution of impaired muscle glucose clearance to reduced postabsorptive systemic glucose clearance in NIDDM. Diabetes 39, 211-216

7. Consoli A. (1-3-1992) Role of liver in pathophysiology of NIDDM. Diabetes Care 15, 430441

8. Reaven G.M. (2014) Pathophysiology of insulin resistance in human disease. Physiol Rev 75, 473-486

9. Reaven G.M. (1-12-1988) Role of insulin resistance in human disease. Diabetes 37, 15951607

10. Ritzel R.A., Butler A.E., Rizza R.A., Veldhuis J.D., Butler P.C. (1-3-2006) Relationship between b-cell mass and fasting blood glucose concentration in humans. Diabetes Care 29, 717-718

11. The Diabetes Control and Complications Trial Research Group (30-9-1993) The Effect of Intensive Treatment of Diabetes on the Development and Progression of Long-Term Complications in Insulin-Dependent Diabetes Mellitus. N Engl J Med 329, 977-986

12. UK Prospective Diabetes Study (UKPDS) Group (1998) Effect of intensive blood-glucose control with metformin on complications in overweight patients with type 2 diabetes (UKPDS 34). The Lancet $352,854-865$

13. UK Prospective Diabetes Study (UKPDS) Group (1998) Intensive blood-glucose control with sulphonylureas or insulin compared with conventional treatment and risk of complications in patients with type 2 diabetes (UKPDS 33). The Lancet 352, 837-853

14. American Diabetes Association (1-1-2011) Executive Summary: Standards of Medical Care in Diabetes - 2011. Diabetes Care 34, S4-S10

15. Nathan D.M., Buse J.B., Davidson M.B., Ferrannini E., Holman R.R., Sherwin R., Zinman B. (1-1-2009) Medical management of hyperglycemia in type 2 diabetes: A consensus algorithm for the initiation and adjustment of therapy: A consensus statement of the American Diabetes Association and the European Association for the Study of Diabetes. Diabetes Care 32, 193203 
16. Nathan D.M., Buse J.B., Davidson M.B., Heine R.J., Holman R.R., Sherwin R., Zinman B. (1-8-2006) Management of Hyperglycemia in Type 2 Diabetes: A Consensus Algorithm for the Initiation and Adjustment of Therapy: A consensus statement from the American Diabetes Association and the European Association for the Study of Diabetes. Diabetes Care 29, 1963 1972

17. The ADVANCE Collaborative Group (12-6-2008) Intensive Blood Glucose Control and Vascular Outcomes in Patients with Type 2 Diabetes. N Engl J Med 358, 2560-2572

18. The Action to Control Cardiovascular Risk in Diabetes Study Group (12-6-2008) Effects of Intensive Glucose Lowering in Type 2 Diabetes. N Engl J Med 358, 2545-2559

19. Herman W.H., Dirani R.G., O'Neill M.C., Kravitz B., Heise A., Bakst A., Freed.M.I. (2005) Reduction in use of healthcare services with combination sulfonylurea and rosiglitazone: findings from the Rosiglitazone Early vs SULfonylurea Titration (RESULT) study. Am J Manag Care 11, 273-278

20. Proks P., Reimann F., Green N., Gribble F., Ashcroft F. (2002) Sulfonylurea stimulation of insulin secretion. Diabetes 51, S368-S376

21. Nichols C.G. (2006) KATP channels as molecular sensors of cellular metabolism. Nature $440,470-476$

22. Ashcroft F.M. (2007) ATP-sensitive K channels and disease: from molecule to malady. Am $J$ Physiol - Endocrinol Metab 293, E880-E889

23. Inagaki N., Gonoi T., Clement J.P., Wang C.Z., Aguilar-Bryan L., Bryan J., Seino S. (1996) A family of sulfonylurea receptors determines the pharmacological properties of ATPSensitive $\mathrm{K}^{+}$channels. Neuron 16, 1011-1017

24. Aittoniemi J., Fotinou C., Craig T.J., de Wet H., Proks P., Ashcroft F.M. (2009) SUR1: a unique ATP-binding cassette protein that functions as an ion channel regulator. Phil Trans $R$ Soc B 364, 257-267

25. Gribble F.M., Tucker S.J., Seino S., Ashcroft F.M. (1-9-1998) Tissue specificity of sulfonylureas: studies on cloned cardiac and beta-cell K(ATP) channels. Diabetes 47, 1412 1418

26. Zünkler B.J., Lenzen S., Männer K., Panten U., Trube G. (2014) Concentration-dependent effects of tolbutamide, meglitinide, glipizide, glibenclamide and diazoxide on ATP-regulated $\mathrm{K}^{+}$currents in pancreatic b-cells. Naunyn-Schmiedeberg's Arch Pharmacol 337, 225-230

27. Sturgess N.C., Kozlowski R.Z., Carrington C.A., Hales C.N., Ashford M.L. (1988) Effects of sulphonylureas and diazoxide on insulin secretion and nucleotide-sensitive channels in an insulin-secreting cell line. Br J Pharmacol 95, 83-94

28. Splitter S., Brown F.R., Friskey R.W., Grindell L., Kinsell L.W. (1956) Treatment of diabetic patients-observations on the use of carbutamide and tolbutamide. California Medicine 85, 285-288

29. Graal M.B., Wolffenbuttel B.H.R. (1999) The use of sulphonylureas in the elderly. Drugs and Aging 15, 471-481 
30. Malabu U.H., Vangaveti V.N., Kennedy L.R. (2014) Disease burden evaluation of fall-related events in the elderly due to hypoglycemia and other diabetic complications: a clinical review. Clinical Epidemiology 6, 287-294

31. Bailey C.J., Day C. (1-4-2004) Metformin: its botanical background. Pract Diab Int 21, 115117

32. Bailey C.J. (1-6-1992) Biguanides and NIDDM. Diabetes Care 15, 755-772

33. Tucker G.T., Casey C., Phillips P.J., Connor H., Ward J.D., Woods H.F. (1-8-1981) Metformin kinetics in healthy subjects and in patients with diabetes mellitus. $\mathrm{Br} \mathrm{J} \mathrm{Clin}$ Pharmacol 12, 235-246

34. Zhou M., Xia L., Wang J. (1-10-2007) Metformin transport by a newly cloned protonstimulated organic cation transporter (Plasma Membrane Monoamine Transporter) expressed in human intestine. Drug Metab Dispos 35, 1956-1962

35. Gong L., Goswami S., Giacomini K.M., Altman R.B., Klein T.E. (2012) Metformin pathways: pharmacokinetics and pharmacodynamics. Pharmacogenet Genomics 22, 820-827

36. Graham G.G., Punt J., Arora M., Day R.O., Doogue M.P., Duong J., Furlong T.J., Greenfield J.R., Greenup L.C., Kirkpatrick C.M., Ray J.E., Timmins P., Williams K.M. (2011) Clinical pharmacokinetics of metformin. Clin Pharmacokinet 50, 81-98

37. Strack T. (2008) Metformin: A review. Drugs of Today 44, 303-314

38. Campbell R.K., White J.R., Saulie B.A. (1996) Metformin: a new oral biguanide. Clin Ther $18,360-371$

39. DeFronzo R.A., Goodman A.M. (31-8-1995) Efficacy of Metformin in Patients with NonInsulin-Dependent Diabetes Mellitus. N Engl J Med 333, 541-549

40. Bailey C.J., Turner R.C. (29-2-1996) Metformin. N Engl J Med 334, 574-579

41. Stumvoll M., Nurjhan N., Perriello G., Dailey G., Gerich J.E. (31-8-1995) Metabolic effects of metformin in non-insulin-dependent diabetes mellitus. N Engl J Med 333, 550-554

42. Hundal R.S., Krssak M., Dufour S., Laurent D., Lebon V., Chandramouli V., Inzucchi S.E., Schumann W.C., Petersen K.F., Landau B.R., Shulman G.I. (1-12-2000) Mechanism by which metformin reduces glucose production in type 2 diabetes. Diabetes 49, 2063-2069

43. Klip A., Leiter L.A. (1-6-1990) Cellular mechanism of action of metformin. Diabetes Care $13,696-704$

44. Fryer L.G.D., Parbu-Patel A., Carling D. (12-7-2002) The anti-diabetic drugs rosiglitazone and metformin stimulate AMP-activated protein kinase through distinct signaling pathways. $J$ Biol Chem 277, 25226-25232

45. Hardie D.G. (2008) AMPK: a key regulator of energy balance in the single cell and the whole organism. Int J Obes Relat Metab Disord 32, S7-S12

46. Ruderman N., Prentki M. (2004) AMP-kinase and malonyl-CoA: Targets for therapy of the metabolic syndrome. Nat Rev Drug Disc 3, 340-351 
47. Owen M.R., Doran E., Halestrap A.P. (2000) Evidence that metformin exerts its anti-diabetic effects through inhibition of complex 1 of the mitochondrial respiratory chain. Biochem J 348, 607-614-

48. Sakamoto K., Göransson O., Hardie D.G., Alessi D.R. (2004) Activity of LKB1 and AMPKrelated kinases in skeletal muscle: effects of contraction, phenformin, and AICAR. Am J Physiol - Endocrinol Metab 287, E310-E317-

49. Golay A. (24-7-2007) Metformin and body weight. Int J Obes Relat Metab Disord 32, 61-72

50. Clapham J.C., Arch J.R. (2008) Influencing energy expenditure and substrate utilisation. 101115

51. Paolisso G., Amato L., Eccellente R., Gambardella A., Tagliamonte M.R., Varricchio G., Carella C., Giugliano D., D'onofrio F. (1998) Effect of metformin on food intake in obese subjects. Eur J Clin Invest 28, 441-446

52. Bruijstens L.A., van Luin M., Buscher-Jungerhans P.M., Bosch F.H. (2008) Reality of severe metformin-induced lactic acidosis in the absence of chronic renal impairment. Neth J Med 66, 185-190

53. Carter D., Howlett H.C.S., Wiernsperger N.F., Bailey C.J. (1-3-2003) Differential effects of metformin on bile salt absorption from the jejunum and ileum. Diabetes Obes Metab 5, 120125

54. Davidson J., Howlett H. (1-7-2004) New prolonged-release metformin improves gastrointestinal tolerability. The British Journal of Diabetes \& Vascular Disease 4, 273-277

55. Mallick S. (2004) Metformin induced acute pancreatitis precipitated by renal failure. Postgraduate Medical Journal 80, 239-240

56. Alsubaie S., Almalki M.H. (1-4-2013) Metformin induced acute pancreatitis. Dermatoendocrinology 5, 317-318

57. Oprea T.I., Bauman J.E., Bologa C.G., Buranda T., Chigaev A., Edwards B.S., Jarvik J.W., Gresham H.D., Haynes M.K., Hjelle B., Hromas R., Hudson L., Mackenzie D.A., Muller C.Y., Reed J.C., Simons P.C., Smagley Y., Strouse J., Surviladze Z., Thompson T., Ursu O., Waller A., Wandinger-Ness A., Winter S.S., Wu Y., Young S.M., Larson R.S., Willman C., Sklar L.A. (2011) Drug repurposing from an academic perspective. Drug Discovery Today: Therapeutic Strategies

58. Kasznicki J., Sliwinska A., Drzewoski J. (15-6-2014) Metformin in cancer prevention and therapy. Ann Transl Med 2, 57-

59. Diamanti-Kandarakis E., Christakou C.D., Kandaraki E., Economou F.N. (1-2-2010) Metformin: an old medication of new fashion: evolving new molecular mechanisms and clinical implications in polycystic ovary syndrome. Eur J Endocrinol 162, 193-212

60. Scarpello J.H.B., Howlett H.C.S. (1-9-2008) Metformin therapy and clinical uses. Diab Vasc Dis Res 5, 157-167

61. Hirst J.A., Farmer A.J., Dyar A., Lung T.W.C., Stevens R.J. (2013) Estimating the effect of sulfonylurea on HbA1c in diabetes: a systematic review and meta-analysis. Diabetologia 56, 973-984 
62. Rydberg T., Jönsson A., Karlsson M.O., Melander A. (1-4-1997) Concentration-effect relations of glibenclamide and its active metabolites in man: modelling of Pharmacokinetics and Pharmacodynamics. Br J Clin Pharmacol 43, 373-381

63. Kola I., Landis J. (2004) Can the pharmaceutical industry reduce attrition rates? Nat Rev Drug Disc 3, 711-716

64. Rosengren A., Jing X., Eliasson L., Renstrøm E. (28-10-2008) Why Treatment Fails in Type 2 Diabetes. PLoS Med 5, e215-

65. Kahn S.E., Haffner S.M., Heise M.A., Herman W.H., Holman R.R., Jones N.P., Kravitz B.G., Lachin J.M., O'Neill M.C., Zinman B., Viberti G. (7-12-2006) Glycemic durability of rosiglitazone, metformin, or glyburide monotherapy. N Engl J Med 355, 2427-2443

66. Karam J.H., Sanz N., Salamon E., Nolte M.S. (1-12-1986) Selective unresponsiveness of pancreatic b-cells to acute sulfonylurea stimulation during sulfonylurea therapy in NIDDM. Diabetes 35, 1314-1320

67. Pantalone K.M., Kattan M.W., Yu C., Wells B.J., Arrigain S., Jain A., Atreja A., Zimmerman R.S. (1-9-2012) Increase in overall mortality risk in patients with type 2 diabetes receiving glipizide, glyburide or glimepiride monotherapy versus metformin: a retrospective analysis. Diabetes Obes Metab 14, 803-809

68. Rustenbeck I., Wienbergen A., Bleck C., Jörns A. (1-12-2004) Desensitization of insulin secretion by depolarizing insulin secretagogues. Diabetes 53, S140-S150

69. Sadikot S.M., Mogensen C.E. (2008) Risk of coronary artery disease associated with initial sulphonylurea treatment of patients with type 2 diabetes: A matched case-control study. Diabetes Res Clin Pract 82, 391-395

70. Lefer D.J., Nichols C.G., Coetzee W.A. (2009) Sulfonylurea receptor 1 subunits of ATPsensitive potassium channels and myocardial Ischemia/reperfusion Injury. Trends in Cardiovascular Medicine 19, 61-67

71. Bell D.S.H. (17-1-2006) Do sulfonylurea drugs increase the risk of cardiac events? Canadian Medical Association Journal 174, 185-186

72. Grygiel-Górniak B. (14-2-2014) Peroxisome proliferator-activated receptors and their ligands: nutritional and clinical implications- a review. Nutrition Journal 13, 17-17

73. Glosli H., Gudbrandsen O.A., Mullen A.J., Halvorsen B., Røst T.H., Wergedahl H., Prydz H., Aukrust P., Berge R.K. (2005) Down-regulated expression of PPARa target genes, reduced fatty acid oxidation and altered fatty acid composition in the liver of mice transgenic for hTNFa. Biochim Biophys Acta 1734, 235-246

74. Turner N.C., Clapham J.C. (1998) Insulin resistance, impaired glucose tolerance and noninsulin-dependent diabetes, pathologic mechanisms and treatment: Current status and therapeutic possibilities. Progress in Drug Research 51, 33-94

75. Henry R.R. (1997) Thiazolidinediones. Endocrinology and Metabolism Clinics 26, 553-573

76. Gale E.A.M. (2006) Troglitazone: the lesson that nobody learned? Diabetologia 49, 1-6

77. Barnett A.H. (8-4-2009) Redefining the role of thiazolidinediones in the management of type 2 diabetes. Vasc Health Risk Manag 5, 141-151 
78. Phillips L.S., Grunberger G., Miller E., Patwardhan R., Rappaport E.B., Salzman A. (1-22001) Once- and twice-daily dosing with rosiglitazone improves glycemic control in patients with type 2 diabetes. Diabetes Care 24, 308-315

79. Fonseca V., Rosenstock J., Patwardhan R., Salzman A. (5-4-2000) Effect of metformin and rosiglitazone combination therapy in patients with type 2 diabetes mellitus: A randomized controlled trial. JAMA 283, 1695-1702

80. Poitout V. (1-8-2004) b-cell lipotoxicity: burning fat into heat? Endocrinology 145, 35633565

81. Nolan C.J., Prentki M. (2008) The islet b-cell: fuel responsive and vulnerable. Trends in Endocrinology \& Metabolism 19, 285-291

82. Buckingham R.E., Al-Barazanji K.A., Toseland C.D.N., Slaughter M., Connor S.C., West A., Bond B., Turner N.C., Clapham J.C. (1998) Peroxisome proliferator-activated receptor-g agonist, rosiglitazone, protects against nephropathy and pancreatic islet abnormalities in Zucker fatty rats. Diabetes $47,1326-1334-$

83. Nissen S.E., Wolski K. (14-6-2007) Effect of rosiglitazone on the risk of myocardial infarction and death from cardiovascular causes. $N$ Engl J Med 356, 2457-2471

84. Singh S., Loke Y.K., Furberg C.D. (1-8-2007) Thiazolidinediones and heart failure: A teleoanalysis. Diabetes Care 30, 2148-2153

85. Bloomgarden Z.T. (1-9-2007) The Avandia Debate. Diabetes Care 30, 2401-2408

86. Misbin R.I. (1-12-2007) Lessons From the Avandia Controversy: A new paradigm for the development of drugs to treat type 2 diabetes. Diabetes Care 30, 3141-3144

87. Bhatt D.L., Chew D.P., Grines C., Mukherjee D., Leesar M., Gilchrist I.C., Corbelli J.C., Blankenship J.C., Eres A., Steinhubl S., Tan W.A., Resar J.R., Al Mahameed A., Abdel-Latif A., Tang H.W., Brennan D., McErlean E., Hazen S.L., Topol E.J. (2007) Peroxisome proliferator-activated receptor g agonists for the prevention of adverse events following percutaneous coronary revascularizationG-results of the PPAR study. American Heart Journal 154, 137-143

88. McAfee A.T., Koro C., Landon J., Ziyadeh N., Walker A.M. (1-7-2007) Coronary heart disease outcomes in patients receiving antidiabetic agents. Pharmacoepidem Drug Safe 16, 711-725

89. Home P.D., Pocock S.J., Beck-Nielsen H., Gomis R., Hanefeld M., Dargie H., Komajda M., Gubb J., Biswas N., Jones N.P. (2005) Rosiglitazone Evaluated for Cardiac Outcomes and Regulation of Glycaemia in Diabetes (RECORD): study design and protocol. Diabetologia $48,1726-1735$

90. Hillaire-Buys D., Faillie J.L., Montastruc J.L. (2011) Pioglitazone and bladder cancer. The Lancet 378, 1543-1544

91. Grey A. (1-4-2009) Thiazolidinedione-induced skeletal fragility - mechanisms and implications. Diabetes Obes Metab 11, 275-284

92. Oshitari T., Asaumi N., Watanabe M., Kumagai K., Mitamura Y. (2008) Severe macular edema induced by pioglitazone in a patient with diabetic retinopathy: a case study. Vasc Health Risk Manag 4, 1137-1140 
93. Liazos E., Broadbent D.M., Beare N., Kumar N. (1-7-2008) Spontaneous resolution of diabetic macular oedema after discontinuation of thiazolidenediones. Diabet Med 25, 860-862

94. Cordain L., Eaton S.B., Sebastian A., Mann N., Lindeberg S., Watkins B.A., O'Keefe J.H., Brand-Miller J. (1-2-2005) Origins and evolution of the Western diet: health implications for the 21st century. The American Journal of Clinical Nutrition 81, 341-354

95. Prentice A.M., Jebb S.A. (1995) Obesity in Britain: gluttony or sloth? Brit Med J 311, 437439

96. Röder P.V., Geillinger K.E., Zietek T.S., Thorens B., Koepsell H., Hannelore D. (2014) The role of SGLT1 and GLUT2 in intestinal glucose transport and sensing. PLOS ONE 9, e89977-

97. Caspary W.F. (1-1-1992) Physiology and pathophysiology of intestinal absorption. The American Journal of Clinical Nutrition 55, 299S-308S

98. Chiba S. (1997) Molecular mechanism in alpha-glucosidase and glucoamylase. Biosci Biotechnol Biochem 61, 1233-1239

99. Göke B., Fuder H., Wieckhorst G., Theiss U., Stridde E., Littke T., Kleist P., Arnold R., Lücker P.W. (1995) Voglibose (AO-128) Is an efficient a-Glucosidase inhibitor and mobilizes theendogenous GLP-1 reserve. Digestion 56, 493-501

100. Standl E., Schernthaner G., Rybka J., Hanefeld M., Raptis S.A., Naditch L. (2001) Improved glycaemic control with miglitol in inadequately-controlled type 2 diabetics. Diabetes Res Clin Pract 51, 205-213

101. Hanefeld M., Fischer S., Schulze J., Spengler M., Wargenau M., Schollberg K., Fücker K. (18-1991) Therapeutic potentials of acarbose as first-line drug in NIDDM insufficiently treated with diet alone. Diabetes Care 14, 732-737

102. Salman S., Salman F., Satman I., Yilmaz Y., Özer E., Sengül A., Özer H., Demirel H.O., Karsidag K., Dinççag N., Yilmaz M.T. (2001) Comparison of acarbose and gliclazide as firstline agents in patients with type 2 diabetes. Curr Med Res Opin 16, 296-306

103. Wang G., Liu J., Yang N., Gao X., Fan H., Xu Y., Yang W. (22-8-2014) MARCH2:comparative assessment of therapeutic effects of acarbose and metformin in newly diagnosed type 2 diabetes patients. PLOS ONE 9, e105698-

104. Dabhi A.S., Bhatt N.R., Shah M.J. (15-12-2013) Voglibose: an alpha glucosidase inhibitor. $J$ Clin Diagn Res 7, 3023-3027

105. Standl E., Theodorakis M.J., Erbach M., Schnell O., Tuomilehto J. (16-4-2014) On the potential of acarbose to reduce cardiovascular disease. Cardiovascular Diabetology 13, 81-81

106. Ceriello A., Taboga C., Giacomello R., Stel L., Motz E., Pirisi M. (1996) Post-meal coagulation activation in diabetes mellitus: the effect of acarbose. Diabetologia 39, 469-473

107. Kawano H., Motoyama T., Hirashima O., Hirai N., Miyao Y., Sakamoto T., Kugiyama K., Ogawa H., Yasue H. (1999) Hyperglycemia rapidly suppresses flow-mediated endotheliumdependent vasodilation of brachial artery. J Am Coll Cardiol 34, 146-154

108. Heitzer T., Schlinzig T., Krohn K., Meinertz T., Münzel T. (27-11-2001) Endothelial dysfunction, oxidative stress, and risk of cardiovascular events in patients with coronary artery disease. Circulation 104, 2673-2678 
109. Caumo A., Luzi L. (1-9-2004) First-phase insulin secretion: does it exist in real life? Considerations on shape and function. Am J Physiol - Endocrinol Metab 287, E371-E385

110. Lewis G.F., Zinman B., Groenewoud Y., Vranic M., Giacca A. (1-4-1996) Hepatic glucose production is regulated both by direct hepatic and extrahepatic effects of insulin in Humans. Diabetes 45, 454-462

111. Calles-Escandon J., Robbins D.C. (1-10-1987) Loss of early phase of insulin release in humans impairs glucose tolerance and blunts thermic effect of glucose. Diabetes 36, 1167 1172

112. Del Prato S., Miccoli R., Penno G. (2005) The importance of effective early phase insulin secretion. Br J Diabetes Vasc Dis 5, 198-202

113. Gerich J.E. (1-2-2002) Is reduced first-phase insulin release the earliest detectable abnormality in individuals destined to develop type 2 diabetes? Diabetes 51, S117-S121

114. Bruce D.G., Chisholm D.J., Storlien L.H., Kraegen E.W. (1-6-1988) Physiological importance of deficiency in early prandial insulin secretion in non-insulin-dependent diabetes. Diabetes $37,736-744$

115. Luzio S.D., Owens D.R., Vora J., Dolben J., Smith H. (1991) Intravenous insulin simulates early insulin peak and reduces post-prandial hyperglycaemia/hyperinsulinaemia in type 2 (non-insulin-dependent) diabetes mellitus. Diabetes Research 16, 63-67

116. Owens D.R., Luzio S.D., Ismail I., Bayer T. (1-4-2000) Increased prandial insulin secretion after administration of a single preprandial oral dose of repaglinide in patients with type 2 diabetes. Diabetes Care 23, 518-523

117. Gromada J., Dissing S., Kofod H., Frøkjær-Jensen J. (1995) Effects of the hypoglycaemic drugs repaglinide and glibenclamide on ATP-sensitive potassium-channels and cytosolic calcium levels in TC3 cells and rat pancreatic beta cells. Diabetologia 38, 1025-1032

118. Hu S., Wang S., Fanelli B., Bell P.A., Dunning B.E., Geisse S., Schmitz R., Boettcher B.R. (1-5-2000) Pancreatic b-cell K ATP channel activity and membrane-binding studies with nateglinide: A comparison with sulfonylureas and repaglinide. J Pharmacol Exp Ther 293, $444-452$

119. Moses R.G., Gomis R., Frandsen K.B., Schlienger J.L., Dedov I. (1-1-2001) Flexible mealrelated dosing with repaglinide facilitates glycemic control in therapy-naive Type 2 Diabetes. Diabetes Care 24, 11-15

120. Rosenstock J., Hassman DR., Madder R.D., Brazinsky S.A., Farrell J., Khutoryansky N., Hale P.M. (1-6-2004) Repaglinide versus nateglinide monotherapy: A randomized, multicenter study. Diabetes Care 27, 1265-1270

121. Hansen A.M., Christensen I.T., Hansen J.B., Carr R.D., Ashcroft F.M., Wahl P. (1-9-2002) Differential interactions of nateglinide and repaglinide on the human b-cell sulphonylurea receptor 1. Diabetes 51, 2789-2795

122. Madsbad S., Kilhovd B., Lager I., Mustajoki P., Dejgaard A., for the Scandinavian Repaglinide Group (1-5-2001) Comparison between repaglinide and glipizide in type 2 diabetes mellitus: a 1-year multicentre study. Diabet Med 18, 395-401 
123. Inzucchi S.E., Bergenstal R.M., Buse J.B., Diamant M., Ferrannini E., Nauck M., Peters A.L., Tsapas A., Wender R., Matthews D.R. (22-5-2012) Management of Hyperglycemia in Type 2 Diabetes: A Patient-Centered Approach. Diabetes Care 35, 1364-

124. Ekström N., Svensson A.M., Miftaraj M., Andersson S.K., Cederholm J., Zethelius B., Eliasson B., Gudbj+Ârnsdottir S. (19-3-2015) Durability of oral hypoglycemic agents in drug naïve patients with type 2 diabetes: report from the Swedish National Diabetes Register (NDR). BMJ Open Diab Res Care 3,

125. Moses R., Slobodniuk R., Boyages S., Colagiuri S., Kidson W., Carter J., Donnelly T., Moffitt P., Hopkins H. (1-1-1999) Effect of repaglinide addition to metformin monotherapy on glycemic control in patients with type 2 diabetes. Diabetes Care 22, 119-124

126. Schramm T.K., Gislason G.H., Vaag A., Rasmussen J.N., Folke F., Hansen M.L., Fosbøl E.L., Køber L., Norgaard M.L., Madsen M., Hansen P.R., Torp-Pedersen C. (1-8-2011) Mortality and cardiovascular risk associated with different insulin secretagogues compared with metformin in type 2 diabetes, with or without a previous myocardial infarction: a nationwide study. Eur Heart J 32, 1900-1908

127. Creutzfeldt W. (15-6-2005) The [pre-] history of the incretin concept. Regul Pept 128, 87-91

128. Vilsbøll T., Krarup T., Madsbad S., Holst J.J. (15-7-2003) Both GLP-1 and GIP are insulinotropic at basal and postprandial glucose levels and contribute nearly equally to the incretin effect of a meal in healthy subjects. Regul Pept 114, 115-121

129. Eissele R., Göke R., Willemer S., Harthus H.P., Vermeer H., Arnold R., Göke B. (1992) Glucagon-like peptide-1 cells in the gastrointestinal tract and pancreas of rat, pig and man. Eur J Clin Invest 22, 283-291

130. Gorboulev V., Schürmann A., Vallon V., Kipp H., Jaschke A., Klessen D., Friedrich A., Scherneck S., Rieg T., Cunard R., Veyhl-Wichmann M., Srinivasan A., Balen D., Breljak D., Rexhepaj R., Parker H.E., Gribble F.M., Reimann F., Lang F., Wiese S., Sabolic I., Sendtner M., Koepsell H. (1-1-2012) $\mathrm{Na}^{+}$-d-glucose cotransporter SGLT1 is pivotal for intestinal glucose absorption and glucose-dependent incretin secretion. Diabetes 61, 187-196

131. Thorens B. (15-9-1992) Expression cloning of the pancreatic beta cell receptor for the glucoincretin hormone glucagon-like peptide 1. PNAS 89, 8641-8645

132. Dillon J.S., Tanizawa Y., Wheeler M.B., Leng X.H., Ligon B.B., Rabin D.U., Yoo-Warren H., Permutt M.A., Boyd A.E. (1-10-1993) Cloning and functional expression of the human glucagon-like peptide-1 (GLP-1) receptor. Endocrinology 133, 1907-1910

133. Gremlich S., Porret A., Hani E.H., Cherif D., Vionnet N., Froguel P., Thorens B. (1-10-1995) Cloning, functional expression, and chromosomal localization of the human pancreatic islet glucose-dependent insulinotropic polypeptide receptor. Diabetes 44, 1202-1208

134. Seino Y., Fukushima M., Yabe D. (22-4-2010) GIP and GLP-1, the two incretin hormones: Similarities and differences. J Diabetes Invest 1, 8-23

135. Salon J.A., Lodowski D.T., Palczewski K. (1-12-2011) The significance of G ProteinCoupled Receptor crystallography for drug discovery. Pharmacol Rev 63, 901-937

136. Wang M.W., Liu Q., Zhou C. (2-9-2010) Non-peptidic glucose-like peptide-1 receptor agonists: aftermath of a serendipitous discovery. Acta Pharmacol Sin 31, 1026-1030 
137. Su H., He M., Li H., Liu Q., Wang J., Wang Y., Gao W., Zhou L., Liao J., Young A.A., Wang M.W. (6-8-2008) Boc5, a non-peptidic Glucagon-Like Peptide-1 receptor agonist, invokes sustained glycemic control and weight loss in diabetic mice. PLOS ONE 3, e2892-

138. Chen D., Liao J., Li N., Zhou C., Liu Q., Wang G., Zhang R., Zhang S., Lin L., Chen K., Nan F., Young A.A., Wang M.W. (16-1-2007) A nonpeptidic agonist of glucagon-like peptide 1 receptors with efficacy in diabetic db/db mice. Proc Natl Acad Sci U S A 104, 943-948

139. Kolterman O.G., Kim D.D., Shen L., Ruggles J.A., Nielsen L.L., Fineman M.S., Baron A.D. (2005) Pharmacokinetics, pharmacodynamics, and safety of exenatide in patients with type 2 diabetes mellitus. American Journal of Health-System Pharmacy 62, 173-181

140. Agers $\varnothing$ H., Jensen L.B., Elbrønd B., Rolan P., Zdravkovic M. (2002) The pharmacokinetics, pharmacodynamics, safety and tolerability of NN2211, a new long-acting GLP-1 derivative, in healthy men. Diabetologia 45, 195-202

141. Cai Y., Wei L., Ma L., Huang X., Tao A., Liu Z., Yuan W. (2013) Long-acting preparations of exenatide. Drug Design, Development and Therapy 7, 963-970

142. Hansen K.B., Vilsbøll T., Knop F.K. (2010) Incretin mimetics: a novel therapeutic option for patients with type 2 diabetes - a review. Diabetes Metab Syndr Obes 17, 155-163

143. Pinkney J., Fox T., Ranganath L. (2010) Selecting GLP-1 agonists in the management of type 2 diabetes: differential pharmacology and therapeutic benefits of liraglutide and exenatide.

Therapeutics and Clinical Risk Management 6, 401-411

144. Schlögl H., Kabisch S., Horstmann A., Lohmann G., Müller K., Lepsien J., Busse-Voigt F., Kratzsch J., Pleger B., Villringer A., Stumvoll M. (2013) Exenatide-induced reduction in energy intake is associated with increase in hypothalamic connectivity. Diabetes Care 36, 1933-1940

145. Edwards C.M., Stanley S.A., Davis R., Brynes A.E., Frost G.S., Seal L.J., Ghatei M.A., Bloom S.R. (2001) Exendin-4 reduces fasting and postprandial glucose and decreases energy intake in healthy volunteers. Am J Physiol - Endocrinol Metab 281, E155-E161

146. Ando T., Haraguchi A., Matsunaga T., Natsuda S., Yamasaki H., Usa T., Kawakami A. (2014) Liraglutide as a potentially useful agent for regulating appetite in diabetic patients with hypothalamic hyperphagia and obesity. Internal Medicine 53, 1791-1795

147. Zoicas F., Droste M., Mayr B., Buchfelder M., Schöfl C. (2013) GLP-1 analogues as a new treatment option for hypothalamic obesity in adults: report of nine cases. Eur J Endocrinol $168,699-706$

148. Matveyenko A.V., Butler P.C. (2008) Relationship between b-cell mass and diabetes onset. Diabetes Obes Metab 10, 23-31

149. Demeterco C., Hao E., Lee S.H., Itkin-Ansari P., Levine F. (2009) Adult human b-cell neogenesis? Diabetes Obes Metab 11, 46-53

150. Bunck M.C., CornÃ@r A., Eliasson B., Heine R.J., Shaginian R.M., Taskinen M.R., Smith U., Yki-JÃarvinen H., Diamant M. (2011) Effects of exenatide on measures of b-cell function after 3 years in metformin-treated patients with type 2 diabetes. Diabetes Care 34, 2041-2047 
151. Kjems L.L., Holst J.J., Vølund A., Madsbad S. (2003) The influence of GLP-1 on glucosestimulated insulin secretion: effects on $\beta$-cell sensitivity in type 2 and nondiabetic subjects. Diabetes 52, 380-386

152. Mondragon A., Davidsson D., Kyriakoudi S., Bertling A., Gomes-Faria R., Cohen P., Rothery S., Chabosseau P., Rutter G.A., da Silva Xavier G. (2014) Divergent effects of liraglutide, exendin-4, and sitagliptin on beta-cell mass and indicators of pancreatitis in a mouse model of hyperglycaemia. PLOS ONE 9, e104873-

153. Rutti S., Sauter N.S., Bouzakri K., Prazak R., Halban P.A., Donath M.Y. (2012) In vitro proliferation of adult human beta-cells. PLOS ONE 7, e35801-

154. Toso C., McCall M., Emamaullee J., Merani S., Davis J., Edgar R., Pawlick R., Kin T., Knudsen L.B., Shapiro A.M.J. (2010) Liraglutide, a long-acting human glucagon-like peptide 1 analogue, improves human islet survival in culture. Transplant International 23, 259-265

155. Bregenholt S., Møldrup A., Blume N., Karlsen A.E., Friedrichsen B.N., Tornhave D., Knudsen L.B., Petersen J.S. (2005) The long-acting glucagon-like peptide-1 analogue, liraglutide, inhibits b-cell apoptosis in vitro. Biochem Biophys Res Commun 330, 577-584

156. Butler A.E., Janson J., Bonner-Weir S., Ritzel R., Rizza R.A., Butler P.C. (2003) b-Cell deficit and Increased $\beta$-cell apoptosis in humans with type 2 diabetes. Diabetes 52, 102-110

157. Bosco D., Armanet M., Morel P., Niclauss N., Sgroi A., Muller Y.D., Giovannoni L., Parnaud G., Berney T. (2010) Unique arrangement of $\alpha$ - and $\beta$-cells in human Islets of Langerhans. Diabetes 59, 1202-1210

158. Cabrera O., Berman D.M., Kenyon N.S., Ricordi C., Berggren P.O., Caicedo A. (2006) The unique cytoarchitecture of human pancreatic islets has implications for islet cell function. Proc Natl Acad Sci U S A 103, 2334-2339

159. Steiner DJ., Kim A., Miller K., Hara M. (2010) Pancreatic islet plasticity: Interspecies comparison of islet architecture and composition. Islets 2, 135-145

160. Butler P.C., Elashoff M., Elashoff R., Gale E.A.M. (2013) A critical analysis of the clinical use of incretin-based therapies: Are the GLP-1 therapies safe? Diabetes Care 36, 2118-2125

161. Perfetti R., Zhou J., Doyle M.E., Egan J.M. (2000) Glucagon-Like Peptide-1 induces cell proliferation and pancreatic-duodenum homeobox-1 expression and increases endocrine cell mass in the pancreas of old, glucose intolerant rats. Endocrinology 141, 4600-4605

162. Nauck M.A., Friedrich N. (2013) Do GLP-1-based therapies increase cancer risk? Diabetes Care 36, S245-S252

163. Noel R.A., Braun D.K., Patterson R.E., Bloomgren G.L. (2009) Increased risk of acute pancreatitis and biliary disease observed in patients with type 2 diabetes: a retrospective cohort study. Diabetes Care 32, 834-838

164. David F., Bernard A.M., Pierres M., Marguet D. (1993) Identification of serine 624, aspartic acid 702, and histidine 734 as the catalytic triad residues of mouse dipeptidyl-peptidase IV (CD26). A member of a novel family of nonclassical serine hydrolases. J Biol Chem 268, $17247-17252$

165. Lankas G.R., Leiting B., Roy R.S., Eiermann G.J., Beconi M.G., Biftu T., Chan C.C., Edmondson S., Feeney W.P., Huaibing H., Ippolito D.E., Kim D., Lyons K.A., Ok H.O., Patel 
R.A., Petrov A.N., Pryor K.A., Qian X., Reigle L., Woods A., Wu J.K., Zaller D., Zhang X., Zhu L., Weber A.E., Thornberry N.A. (2005) Dipeptidyl peptidase IV inhibition for the treatment of type 2 diabetes: potential importance of selectivity over dipeptidyl peptidases 8 and 9. Diabetes 54, 2988-2994

166. Lambeir A.-M., Durinx C., Scharpé S., De Meester I. (2013) Dipeptidyl-peptidase IV from bench to bedside: An update on structural proterties, functions, and clinical aspects of the enzyme DPPIV. Crit Rev Clin Lab Sci 40, 209-294

167. Durinx C., Lambeir A.M., Bosmans E., Falmagne J.B., Berghmans R., Haemers A., Scharpé S., De Meester I. (2000) Molecular characterization of dipeptidyl peptidase activity in serum. Eur J Biochem 267, 5608-5613

168. Kos K., Baker A.R., Jernas M., Harte A.L., Clapham J.C., O'Hare J.P., Carlsson L., Kumar S., McTernan P.G. (2009) DPP-IV inhibition enhances the antilipolytic action of NPY in human adipose tissue. Diabetes Obes Metab 11_, 285-292

169. Engel M., Hoffmann T., Wagner L., Wermann M., Heiser U., Kiefersauer R., Huber R., Bode W., Demuth H.U., Brandstetter H. (2003) The crystal structure of dipeptidyl peptidase IV (CD26) reveals its functional regulation and enzymatic mechanism. Proc Natl Acad Sci U S A $100,5063-5068$

170. Aertgeerts K., Ye S., Tennant M.G., Kraus M.L., Rogers J., Sang B.C., Skene R.J., Webb D.R., Prasad GS. (2004) Crystal structure of human dipeptidyl peptidase IV in complex with a decapeptide reveals details on substrate specificity and tetrahedral intermediate formation. Protein Sci 13, 412-421

171. Sebokova E., Christ A.D., Boehringer M., Mizrahi J. (2015) Dipeptidyl peptidase IV inhibitors: the next generation of new promising therapies for the management of type 2 diabetes. Curr Topics Med Chem 7, 547-555

172. Shubrook J., Colucci R., Guo A., Schwartz F. (2011) Saxagliptin: a selective DPP-4 inhibitor for the treatment of type 2 diabetes mellitus. Clinical Medicine Insights Endocrinology and Diabetes 4, 1-12

173. Toth P.P. (2015) Overview of saxagliptin efficacy and safety in patients with type 2 diabetes and cardiovascular disease or risk factors for cardiovascular disease. Vasc Health Risk Manag $11,9-23$

174. Banerjee M., Younis N., Soran H. (2009) Vildagliptin in clinical practice: a review of literature. Expert Opin Pharmacother 10, 2745-2757

175. Dhillon S. (2010) Sitagliptin: a review of its use in the management of type 2 diabetes mellitus. Drugs 70, 489-512

176. Ahrén B. (2014) Insulin plus incretin: A glucose-lowering strategy for type 2-diabetes. World $J$ Diabetes 5, 40-51

177. Pratley R.E., Schweizer A., Rosenstock J., Foley J.E., Banerji M.A., Pi-Sunyer F.X., Mills D., Dejager S. (2008) Robust improvements in fasting and prandial measures of b-cell function with vildagliptin in drug-naïve patients: analysis of pooled vildagliptin monotherapy database. Diabetes Obes Metab 10, 931-938

178. Del Prato S., Barnett A.H., Huisman H., Neubacher D., Woerle H.J., Dugi K.A. (2011) Effect of linagliptin monotherapy on glycaemic control and markers of b-cell function in patients 
with inadequately controlled type 2 diabetes: a randomized controlled trial. Diabetes Obes Metab 13, 258-267

179. Ahrén B., Pacini G., Tura A., Foley J.E., Schweizer A. (2007) Improved meal-related insulin processing contributes to the enhancement of b-cell function by the DPP-4 inhibitor vldagliptin in patients with type 2 diabetes. Horm Metab Res 39, 826-829

180. Yeom J.A., Kim E.S., Park H.S., Ham D.S., Sun K., Kim J.W., Cho J.H., Yoon K.H. (2011) Both sitagliptin analogue \& pioglitazone preserve the beta-cell proportion in the islets with different mechanism in non-obese and obese diabetic mice. BMB Reports 44, 713-718

181. Girgis C.M., Champion B.L. (2011) Vildagliptin-induced acute pancreatitis. Endocr Pract 17, e48-e50

182. Lee C.F., Sun M.S., Tai Y.K. (2014) Saxagliptin-induced recurrent acute pancreatitis. Internal Medicine 53, 1351-1354

183. Chang C.H., Lin J.W., Chen S.T., Lai M.S., Cuang L.M., Chang Y.C. (2016) Dipeptidyl peptidase-4 inhibitor use is not associated with acute pancreatitis in high-risk type 2 diabetic patients: a nationwide cohort study. Medicine 95, e2603-e2609

184. Karagiannis T., Bekiari E., Boura P., Tsapas A. (2015) Cardiovascular risk with DPP-4 inhibitors: latest evidence and clinical implications. Ther Adv Drug Saf 7, 36-38

185. Brunton S. (2014) GLP-1 receptor agonists vs. DPP-4 inhibitors for type 2 diabetes: is one approach more successful or preferable than the other? Int J Clin Pract 68, 557-567

186. Wright E.M., Loo D.D.F., Hirayama B.A. (2011) Biology of human sodium glucose transporters. Physiol Rev 91, 733-794

187. Wright E.M. (2001) Renal $\mathrm{Na}^{+}$-glucose cotransporters. American Journal of Physiology Renal Physiology 280, F10-F18

188. Mackenzie B., Loo D.D.F., Panayotova-Heiermann M., Wright E.M. (1996) Biophysical characteristics of the pig kidney Na+/Glucose cotransporter SGLT2 reveal a common mechanism for SGLT1 and SGLT2. J Biol Chem 271, 32678-32683

189. Wells R.G., Pajor A.M., Kanai Y., Turk E., Wright E.M., Hediger M.A. (1992) Cloning of a human kidney cDNA with similarity to the sodium-glucose cotransporter. Am. J. Physiol. Renal Physiol. 263, F459-F465

190. Kanai Y., Lee W.S., You G., Brown D., Hediger M.A. (1994) The human kidney low affinity $\mathrm{Na}$ /glucose cotransporter SGLT2. Delineation of the major renal reabsorptive mechanism for D-glucose. J Clin Invest 93, 397-404

191. DeFronzo R.A., Hompesch M., Kasichayanula S., Liu X., Hong Y., Pfister M., Morrow L.A., Leslie B.R., Boulton D.W., Ching A., LaCreta F.P., Griffen S.C. (2013) Characterization of renal glucose reabsorption in response to dapagliflozin in healthy subjects and subjects with type 2 diabetes. Diabetes Care 36, 3169-3176

192. Calado J., Soto K., Clemente C., Correia P., Rueff J. (2004) Novel compound heterozygous mutations in SLC5A2 are responsible for autosomal recessive renal glucosuria. Hum Genet $114,314-316$ 
193. van den Heuvel L., Assink K., Willemsen M., Monnens L. (2002) Autosomal recessive renal glucosuria attributable to a mutation in the sodium glucose cotransporter (SGLT2). Hum Genet 111, 544-547

194. Gallo L.A., Wright E.M., Vallon V. (2015) Probing SGLT2 as a therapeutic target for diabetes: Basic physiology and consequences. Diab Vasc Dis Res 12, 78-89

195. Rossetti L., Smith D., Shulman G.I., Papachristou D., DeFronzo R.A. (1987) Correction of hyperglycemia with phlorizin normalizes tissue sensitivity to insulin in diabetic rats. J Clin Invest 79, 1510-1515

196. Isaji M. (2011) SGLT2 inhibitors: molecular design and potential differences in effect. Kidney Int 79, S14-S19

197. Nomura S., Sakamaki S., Hongu M., Kawanishi E., Koga Y., Sakamoto T., Yamamoto Y., Ueta K., Kimata H., Nakayama K., Tsuda-Tsukimoto M. (2010) Discovery of canagliflozin, a novel C-glucoside with thiophene ring, as sodium-dependent glucose cotransporter 2 inhibitor for the treatment of type 2 diabetes Mellitus. J Med Chem 53, 6355-6360

198. Meng W., Ellsworth B.A., Nirschl A.A., McCann P.J., Patel M., Girotra R.N., Wu G., Sher P.M., Morrison E.P., Biller S.A., Zahler R., Deshpande P.P., Pullockaran A., Hagan D.L., Morgan N., Taylor J.R., Obermeier M.T., Humphreys W.G., Khanna A., Discenza L., Robertson J.G., Wang A., Han S., Wetterau J.R., Janovitz E.B., Flint O.P., Whaley J.M., Washburn W.N. (2008) Discovery of dapagliflozin: A potent, selective renal sodiumdependent glucose cotransporter 2 (SGLT2) inhibitor for the treatment of type 2 diabetes. $J$ Med Chem 51, 1145-1149

199. Neumiller J.J. (2014) Empagliflozin: a new sodium-glucose co-transporter 2 (SGLT2) inhibitor for the treatment of type 2 diabetes. Drugs Context 3, 212262-

200. Hummel C.S., Lu C., Liu J., Ghezzi C., Hirayama B.A., Loo D.D.F., Kepe V., Barrio J.R., Wright E.M. (2011) Structural selectivity of human SGLT inhibitors. Am J Physiol - Cell Physiol 302, C373-C382

201. Valentine V. (2015) The role of the kidney and sodium-glucose cotransporter-2 inhibition in diabetes management. Clin Diabetes 30, 151-155

202. Kalra S. (2014) Sodium glucose co-transporter-2 (SGLT2) inhibitors: a review of their basic and clinical pharmacology. Diabetes Ther 5, 355-366

203. Dietrich E., Powell J., Taylor J.R. (2013) Canagliflozin: a novel treatment option for type 2 diabetes. Drug Design, Development and Therapy 7, 1399-1408

204. Aylsworth A., Dean Z., VanNorman C., Okere A.N. (2014) Dapagliflozin for the treatment of type 2 diabetes mellitus. Ann Pharmacother 48, 1202-1208

205. Heise T., Seman L., Macha S., Jones P., Marquart A., Pinnetti S., Woerle H.J., Dugi K. (2013) Safety, tolerability, pharmacokinetics, and pharmacodynamics of multiple rising doses of empagliflozin in patients with type 2 diabetes mellitus. Diabetes Ther 4, 331-345

206. Kasichayanula S., Liu X., LaCreta F., Griffen S.C., Boulton D.W. (2014) Clinical pharmacokinetics and pharmacodynamics of dapagliflozin, a selective inhibitor of sodiumglucose co-transporter type 2. Clin Pharmacokinet 53, 17-27 
207. Ghezzi C., Hirayama B.A., Gorraitz E., Loo D.D.F., Liang Y., Wright E.M. (2014) SGLT2 inhibitors act from the extracellular surface of the cell membrane. Physiol Rep 2, e12058-

208. Anderson S.L. (2014) Dapagliflozin efficacy and safety: a perspective review. Ther Adv Drug Saf 5, 242-254

209. Bolinder J., Ljunggren Ö., Kullberg J., Johansson L., Wilding J., Langkilde A.M., Sugg J., Parikh S. (2011) Effects of dapagliflozin on body weight, total fat mass, and regional adipose tissue distribution in patients with type 2 diabetes mellitus with inadequate glycemic control on metformin. The Journal of Clinical Endocrinology \& Metabolism 97, 1020-1031

210. Nauck M.A., Del Prato S., Meier J.J., Durán-García S., Rohwedder K., Elze M., Parikh S.J. (2011) Dapagliflozin versus glipizide as add-on therapy in patients with type 2 diabetes who have inadequate glycemic control with metformin: A randomized, 52-week, double-blind, active-controlled noninferiority trial. Diabetes Care 34, 2015-2022

211. Strojek K., Yoon K.H., Hruba V., Sugg J., Langkilde A., Parikh S. (2014) Dapagliflozin added to glimepiride in patients with type 2 diabetes mellitus sustains glycemic control and weight loss Over 48-weeks: A randomized, double-blind, parallel-group, placebo-controlled trial. Diabetes Ther 5, 267-283

212. Geerlings S., Fonseca V., Castro-Diaz D., List J., Parikh S. (2014) Genital and urinary tract infections in diabetes: Impact of pharmacologically-induced glucosuria. Diabetes Res Clin Pract 103, 373-381

213. Sonesson C., Johansson P.A., Johnsson E., Gause-Nilsson I. (2016) Cardiovascular effects of dapagliflozin in patients with type 2 diabetes and different risk categories: a meta-analysis. Cardiovascular Diabetology 15, 37-

214. MacIsaac R.J., Jerums G., Ekinci E.I. (2016) Cardio-renal protection with empagliflozin. Ann Transl Med 4, 409-412

215. Liakos A., Karagiannis T., Bekiari E., Boura P., Tsapas A. (2014) Update on long-term efficacy and safety of dapagliflozin in patients with type 2 diabetes mellitus. Ther $A d v$ Endocrinol Metab 6, 61-67

216. Sosale B., Sosale A., Bhattacharyya A. (2016) Clinical effectiveness and impact on insulin therapy cost after addition of dapagliflozin to patients with uncontrolled type 2 diabetes. Diabetes Ther 7, 765-776

217. Issandou M., Bouillot A., Brusq J., Forest M., Grillot D., Guillard R., Martin S., Michiels C., Sulpice T., Daugan A. (2009) Pharmacological inhibition of Stearoyl-CoA Desaturase 1 improves insulin sensitivity in insulin-resistant rat models. Eur J Pharmacol 618, 28-36

218. Lepifre F., Christmann-Franck S., Roche D., Leriche C., Carniato D., Charon C., Bozec S., Doare L., Schmidlin F., Lecomte M., Valeur E. (2009) Discovery and structure-guided drug design of inhibitors of 11b-hydroxysteroid-dehydrogenase type I based on a spirocarboxamide scaffold. Bioorg Med Chem Lett In Press, Accepted Manuscript,

219. Birch A.M., Buckett L.K., Turnbull A.V. (2010) DGAT1 inhibitors as anti-obesity and antidiabetic agents. Curr Opin Drug Discov Devel 13, 489-496

220. Kaiser D., Oetjen E. (2014) Something old, something new and something very old: drugs for treating type 2 diabetes. Br J Pharmacol 171, 2940-2950 
221. Ichimura A., Hasegawa S., Kasubuchi M., Kimura I. (2014) Free fatty acid receptors as therapeutic targets for the treatment of diabetes. Frontiers in Pharmacology 5, 236-

222. Miller B.R., Nguyen H., Hu C.J.H., Lin C., Nguyen Q.T. (11-2014) New and emerging drugs and targets for type 2 diabetes: reviewing the evidence. American Health \& Drug Benefits 7 , $452-463$

223. Cornell S. (2015) Continual evolution of type 2 diabetes: an update on pathophysiology and emerging treatment options. Therapeutics and Clinical Risk Management 11, 621-632

224. Morgan S., Grootendorst P., Lexchin J., Cunningham C., Greyson D. (2011) The cost of drug development: A systematic review. Health Policy 100, 4-17

225. Paul S.M., Mytelka D.S., Dunwiddie C.T., Persinger C.C., Munos B.H., Lindborg S.R., Schacht A.L. (2010) How to improve R\&D productivity: the pharmaceutical industry's grand challenge. Nat Rev Drug Disc 9, 203-214

226. Herper M. (2012) The truly staggering cost of inventing new drugs. Forbes http://www.forbes.com/sites/matthewherper/2012/02/10/the-truly-staggering-cost-ofinventing-new-drugs/, 